\title{
ANALISIS YURIDIS KEWENANGAN DISKRESI DAN PERTANGGUNG JAWABAN HUKUM DALAM PELAKSANAAN TUGAS DAN FUNGSI KEPOLISIAN
}

\section{Neovaldo Sitinjak}

Universitas Tarumanagara (UNTRAN) Jakarta, Indonesia

Email: neovaldositinjak@gmail.com

\section{Abstract}

Discretion is an authority given by law to law enforcement officials, especially the Police to act in special situations in accordance with the agency's own judgment and conscience. The problem raised is How the Implementation and Authority in Making Discretionary Decisions Against Minor Crimes in the Legal Area of the South Jayapura Sector Police, What is Legal Responsibility in Making Discretionary Decisions Against Minor Crimes in the Legal Area of the South Jayapura Sector Police. In the writing of this thesis, the author uses the juridical empirical research type, while the approach used is socio-legal research. Making the Discretionary decision that has been handled by the South Jayapura Sector Police in cases of minor theft crimes and also resolved by way of Restorative Justice, the South Jayapura Sector Police through Bhabinkamtibmas take discretionary decisions and conduct mediation by summoning both reporting and reported parties. As part of the state administration process, the Jayapura Selatan Sector Police are also bound by certain laws and procedures, and are controlled and accountable to the law. Likewise with the discretionary decision taken, the decision from the discretion itself really depends on the problems faced as well as the situation and conditions in the field experienced by the Jayapura Selatan Sector Police. Even though Police Discretion is situational and subjective, there is also a legal basis for discretion to be accounted for, so that it does not appear arbitrary.

Keywords: juridical analysis; authority; discretion; legal accountability; police duties and functions

\section{Abstrak}

Diskresi merupakan kewenangan yang diberikan oleh undang-undang kepada aparat penegak hukum, khususnya Polri untuk bertindak dalam situasi khusus sesuai dengan penilaian dan hati nurani instansi sendiri. Tujuan penelitian ini supaya bisa mengukur bagaimana implementasi dan kewenangan dalam mengambil keputusan diskresi terhadap tindak pidana ringan di Wilayah Hukum Kepolisian Sektor Jayapura Selatan, apa tanggung jawab hukum dalam membuat keputusan diskresi terhadap kejahatan ringan di wilayah hukum kepolisian sektor jayapura selatan. Dalam penulisan tesis ini, penulis menggunakan jenis penelitian empiris yuridis, sedangkan pendekatan yang digunakan adalah penelitian sosial hukum. Mengambil keputusan diskresi yang telah ditangani oleh kepolisian sektor Jayapura Selatan dalam kasus tindak pidana pencurian ringan dan juga diselesaikan dengan cara Restorative Justice, Kepolisian Sektor Jayapura Selatan melalui

$\begin{array}{ll}\text { How to cite: } & \text { Sitinjak, Neovaldo (2021) Analisis Yuridis Kewenangan Diskresi Dan Pertanggung Jawaban Hukum } \\ & \text { Dalam Pelaksanaan Tugas Dan Fungsi Kepolisian, 3(6). https://doi.org/10.36418/syntax- } \\ & \text { idea.v3i6.1231 } \\ & \text { 2684-883X } \\ \text { E-ISSN: } & \text { Ridwan Institute }\end{array}$


Bhabinkamtibmas mengambil keputusan diskresi dan melakukan mediasi dengan memanggil pihak pelapor maupun terlapor. Sebagai bagian dari proses administrasi negara, Kepolisian Sektor Jayapura Selatan juga terikat oleh undang-undang dan prosedur tertentu, serta dikendalikan dan dipertanggungjawabkan hukumnya. Demikian juga dengan keputusan diskresi yang diambil, keputusan dari diskresi itu sendiri benar-benar tergantung pada permasalahan yang dihadapi serta situasi dan kondisi di lapangan yang dialami oleh Kepolisian Sektor Jayapura Selatan. Meskipun Diskresi Kepolisian bersifat situasional dan subjektif, ada juga dasar hukum untuk diskresi yang harus dipertanggungjawabkan, sehingga tidak tampak sewenang-wenang

Kata Kunci: analisis yuridis; wewenang; diskresi; akuntabilitas hukum; tugas dan fungsi kepolisian

\section{Pendahuluan}

Secara implisit Bhayangkara Polri merupakan harapan dan teladan bangsa, Bhayangkara Polri adalah harapan karena mengemban tugas-tugas untuk memelihara keamanan dan ketertiban masyarakat. Cita-cita dan citra Bhayangkara sebagai harapan dan teladan bangsa bukan suatu predikat yang dengan cuma-cuma diberikan kepada setiap Bhayangkara Polri, namun eksistensinya perlu diproses, aktivitas serta perjuangan yang paling panjang dan membutuhkan banyak pengorbanan. Bhayangkara harapan dan teladan bangsa perlu direalisasikan dalam pelaksanaan tugas sehingga tidak hanya merupakan simbolis semata (Atmodjo, 2015).

Keamanan suatu negara adalah hal yang sangat penting dalam keberhasilan pelaksanaan pembangunan nasional. Jika suatu negara berada dalam situasi aman, maka selanjutnya yang didambakan oleh masyarakat dan pemerintah adalah suatu kehidupan yang bahagia, sejahtera, adil dan makmur dari para warga negaranya, Faktor keamanan tersebut merupakan salah satu tanggung jawab dari Polri (Syaifullah, 2019).

Sebagai bagian dari proses penyelenggara negara, institusi Kepolisian pun terikat kepada aturan-aturan Hukum dan prosedur-prosedur tertentu, serta dikontrol dan bertanggung jawab kepada hukum. Dalam rangka menciptakan anggota Polri yang bersih dari perbuatan tercela, seorang anggota Polri memiliki pedoman bersifat mengikat yang wajib untuk ditaati yang dikenal dengan peraturan disiplin anggota Polri yang diatur tersendiri dalam Peraturan Pemerintah Republik Indonesia Nomor 2 Tahun 2003 tentang Disiplin Anggota Polri. Peraturan di siplin anggota Polri dimaknai sebagai kaidah atau norma yang mengatur dan menjadi pedoman bagi setiap anggota Polri dalam menjalankan tugas dan wewenangnya sebagai Kepolisian Negara.

Selanjutnya dalam melaksanakan tugas profesinya, polisi memiliki kewenangan Diskresi yang dapat dilaksanakan dalam keadaan tertentu. Diskresi dapat dilakukan oleh aparat kepolisian dalam praktik dalam hal bertujuan untuk mengutamakan pencapaian tujuan sasarannya dari pada keberlakuan hukum yang ada. Untuk dapat dilaksanakannya Diskresi, harus terpenuhi tiga syarat yakni demi kepentingan umum, masih dalam lingkup kewenangannya dan tidak melanggar asas-asas umum pemerintahan yang baik.

Diskresi adalah sebuah wewenang yang diberikan hukum kepada aparat penegak hukum, khususnya Kepolisian untuk bertindak dalam situasi khusus sesuai dengan 
penilaian dan kata hati instansi atau petugas sendiri (Sitinjak, 2021). Diskresi sesungguhnya merupakan kelengkapan dari sistem pengaturan oleh hukum itu sendiri. Dengan kewenangan seperti itu, seharusnya aparat Kepolisian lebih jeli dalam penerapan hukum kepada masyarakat dengan melihat substansi perkara yang akan dilanjutkan proses penanganannya sehingga tidak melukai rasa keadilan masyarakat. Hal inilah yang kemudian harus dikaji, apakah pemberian kewenangan Diskresi yang telah diberikan Undang-undang kepada pihak Kepolisian untuk memilah milah perkara yang akan diproses lebih lanjut telah dapat digunakan dengan baik oleh pihak Kepolisian sehingga dapat mencerminkan rasa keadilan dan profesionalisme Polri.

Secara yuridis dalam Undang-undang Republik Indonesia Nomor 2 Tahun 2002 tentang Kepolisian dan Undang undang Republik Indonesia Nomor 8 Tahun 1981 tentang KUHAP, dan Pasal 15 ayat (2) huruf k jo. Pasal 16 ayat (1) huruf 1 menyebutkan "Dalam rangka menyelenggarakan tugas di bidang proses pidana, Polri berwenang untuk mengadakan tindakan lain dalam bentuk tindakan penyelidikan dan penyidikan yang dilaksanakan sebagai berikut:

a. Tidak bertentangan dengan suatu aturan hukum,

b. Selaras dengan kewajiban hukum yang mengharuskan tindakan tersebut dilakukan

c. Harus patut, masuk akal, dan termasuk dalam lingkungan jabatannya,

d. Pertimbangan yang layak berdasarkan keadaan yang memaksa dan

e. Menghormati hak asasi manusia".

Ada beberapa peristiwa dalam praktik, tindakan untuk mengesampingkan perkara dalam rangka menahan atau tidak melakukan penahanan terhadap tersangka/pelaku pelanggaran hukum atau menghentikan proses penyidikan, atau melakukan tindakan seketika bukanlah tindakan Diskresi individual petugas Kepolisian. Tindakan tersebut merupakan tindakan Diskresi birokrasi karena dalam pengambilan keputusan Diskresi berdasarkan atau berpedoman pada kebijaksanaan-kebijaksanaan pimpinan dalam organisasi dan hal tersebut telah dijadikan kesepakatan diantara mereka (Agung, 2012).

Pada beberapa kasus banyak penggunaan Diskresi Kepolisian dilakukan dalam bentuk penyelesaian perkara secara Restorative Justice, Restorative Justice merupakan suatu pendekatan yang lebih menitik-beratkan pada kondisi terciptanya keadilan dan keseimbangan bagi pelaku Tindak Pidana serta korbannya sendiri. Mekanisme tata acara dan peradilan pidana yang berfokus pada pemidanaan diubah menjadi proses dialog dan mediasi untuk menciptakan kesepakatan atas penyelesaian perkara pidana yang lebih adil dan seimbang bagi pihak korban dan pelaku (Hambali, 2020).

Meskipun pada dasarnya aturan tertulis yang mengatur tentang peristiwa tersebut sudah sangat jelas tertulis dalam ketentuan undang-undang seperti tindak pidana pencurian ringan. Dalam perkara pencurian ringan, kebijakan Restorative Justice tentunya memiliki dasar hukum sebagai acuan aparat penegak hukum yaitu Peraturan Mahkamah Agung Republik Indonesia Nomor 2 Tahun 2012 tentang batasan tindak pidana ringan.

Didalam tafsiran Pasal 362 KUHP menentukan bahwa barang siapa mengambil barang sesuatu, yang seluruhnya atau sebagian kepunyaan orang lain, dengan maksud 
untuk dimiliki secara melawan hukum, diancam karena pencurian, dengan pidana penjara paling lama 5 (lima) tahun atau pidana denda paling banyak Rp.900.000,00(sembilan ratus ribu rupiah). Sedangkan Pasal 364 KUHP menentukan bahwa perbuatan yang diterangkan dalam Pasal 362 dan Pasal 363 butir 4, begitu pun perbuatan yang diterangkan dalam Pasal 363 butir 5, apabila tidak dilakukan dalam sebuah rumah atau pekarangan tertutup yang ada rumahnya, jika harga barang yang dicuri tidak lebih dari Rp.25.000,00- (dua puluh lima rupiah), diancam karena pencurian ringan dengan pidana penjara paling lama 3 (tiga) bulan atau pidana denda paling banyak Rp.250,000,00- (dua ratus lima puluh rupiah).

Namun di dalam praktiknya apabila pencurian yang nilainya di bawah 2,5 juta rupiah perbuatan tersebut dapat dikatakan dengan tindak pidana ringan yang dapat di selesaikan secara Restorative Justice berdasarkan Peraturan Mahkamah Agung Republik Indonesia Nomor 2 Tahun 2012 (e) yaitu "Bahwa Peraturan Mahkamah Agung ini sama sekali tidak bermaksud mengubah KUHP, Mahkamah Agung hanya melakukan penyesuaian nilai uang yang sudah sangat tidak sesuai dengan kondisi sekarang ini. Hal ini dimaksudkan memudahkan penegak hukum khususnya hakim, untuk memberikan keadilan terhadap perkara yang diadilinya”.

Yang melatar belakangi lahirnya Peraturan Mahkamah Agung Republik Indonesia Nomor 2 Tahun 2012 ini, yakni upaya pemberian rasa keadilan bagi masyarakat terutama dalam penyelesaian perkara-perkara tindak pidana ringan (Tipiring). Secara teknis hukum yang dinamakan dengan Tipiring adalah suatu tindak pidana yang diancam dengan pidana penjara atau kurungan paling lama tiga bulan dan atau denda sebanyak-banyaknya tujuh ribu lima ratus rupiah dan penghinaan ringan. Oleh sebab itu subtansi Peraturan Mahkamah Agung Republik Indonesia Nomor 2 Tahun 2012 itu sebenarnya bukan pada nilai rupiahnya, tetapi pada tindak-tindak pidana yang ancaman hukumnya paling lama 3 bulan dan itu yang tidak perlu ditahan.

Kemudian dengan adanya penyesuaian denda dalam peraturan Mahkamah Agung Republik Indonesia Nomor 2 Tahun 2012 tentang penyesuaian batasan tindak pidana ringan dan jumlah denda dalam KUHP, diterbitkanlah nota kesepakatan bersama ketua mahkamah agung, menteri hukum dan hak asasi manusia, jaksa agung, kepala Kepolisian Negara Republik Indonesia Nomor 131/Kma/Skb/X/2012 Tahun 2012 tentang pelaksanaan penerapan penyesuaian batasan tindak pidana ringan dan jumlah denda, acara pemeriksaan cepat, serta penerapan keadilan.

Nota Kesepakatan tersebut menyebutkan bahwa Tipiring adalah tindak pidana yang diatur dalam Pasal 364, 373, 379, 384, 407 dan Pasal 482 Kitab Undang-Undang Hukum Pidana ("KUHP”) yang diancam dengan pidana penjara paling lama 3 (tiga) bulan atau denda 10.000 (sepuluh ribu) kali lipat dari denda. Peraturan Mahkamah Agung Republik Indonesia Nomor 2 Tahun 2012 juga harus dibarengi kemampuan penegak hukum untuk mengklasifikasi perkara yang bisa dilihat dari kehidupan sosial pelaku dan korban. Jangan sampai mencederai hak-hak korban, karena pada umumnya dalam suatu kasus hukum korban perlu dapat perlindungan hukum. Sebelum ditetapkannya Peraturan Mahkamah Agung ini, banyak tindak pidana yang meski hanya 
berobyek kecil tapi mendapat hukuman berat. Sementara tak jarang dijumpai pencurian berat tapi berujung pada pembebasan pelakunya.

Sebagaimana telah diketahui di atas pencurian yang nilai di bawah 2.5 Juta Rupiah dapat diselesaikan secara mediasi, dan tidak harus dipidanakan hal ini didasarkan Peraturan Mahkamah Agung Republik Indonesia Nomor 2 Tahun 2012 tentang penyesuaian tindak pidana ringan (Tipiring), Seperti contoh pengambilan keputusan Diskresi yang telah di tangani oleh Kepolisian Sektor Jayapura Selatan terhadap perkara tindak pidana pencurian ringan dan di selesaikan pula dengan cara Restorative Justice ialah kasus pencurian ringan berdasarkan Laporan Polisi Nomor: LP /B-187/ VI / 2019, dari Laporan tersebut dapat di uraikan bahwa pelapor merupakan anak warga kelurahan Ardipura yang dalam laporan tersebut melaporkan pencurian yang dilakukan temannya berupa objek benda tutup pentil variasi ban kendaraan sepeda motor Honda Vario.

Dari laporan LP /B-187/VI/2019 tersebut pihak Kepolisian Sektor Jayapura Selatan tidak serta merta melakukan penindakan/penangkapan mengingat objek benda yang di curi nilainya di bawah 2.5 Juta Rupiah hal ini didasarkan Peraturan Mahkamah Agung Republik Indonesia Nomor: 2 Tahun 2012 tentang batasan tindak pidana ringan yang seharusnya di selesaikan secara restoratif (Restorative Justice), maka pihak Kepolisian Sektor Jayapura Selatan melalui Bhabinkamtibmas mengambil keputusan Diskresi dan melakukan mediasi dengan memanggil kedua belah pihak pelapor maupun terlapor serta melibatkan Yohanes selaku Tokoh masyarakat setempat untuk menyelasaikan perkara pencurian tutup pentil variasi ban kendaraan roda dua Honda Vario.

\section{Metode Penelitian}

Spesifikasi penelitian ini adalah penelitian Deskriptif Analitis, suatu penelitian menggambarkan secara rinci, sistematis dan menyeluruh mengenai segala sesuatu yang berhubungan dengan permasalahan (Cahyaningtyas, 2015) (deskriptif) dimaksudkan untuk memberikan data yang seteliti mungkin tentang manusia, keadaan atau segala yang berkaitan dalam materi lainnya (Fardani, 2021). Dalam hal ini dimaksudkan untuk memberikan gambaran yang jelas tentang permasalahan materi yang diteliti yaitu Analisis Yuridis Kewenangan Diskresi Dan Pertanggung Jawaban Hukum Dalam Pelaksanaan Tugas Dan Fungsi Kepolisian (Studi Kasus Di Kepolisian Sektor Jayapura Selatan).

Penelitian ini menggunakan tipe penelitian Yuridis Empiris, suatu penelitian dengan cara memadukan bahan-bahan hukum (yang merupakan data sekunder) dengan data primer yang diperoleh terhadap fakta fakta hukum yang terjadi dilapangan. Sedangkan pendekatan yang digunakan adalah Socio-Legal Research yaitu melihat Analisis Yuridis Kewenangan Diskresi Dan Pertanggung Jawaban Hukum Dalam Pelaksanaan Tugas Dan Fungsi Kepolisian (Studi Kasus Di Kepolisian Sektor Jayapura Selatan). 
Tehnik pengambilan sampel dilakukan secara Purposive Sampling, yaitu penarikan sampel berdasarkan kriteria tertentu, dimana sampel dipilih dan ditentukan berdasarkan kriteria yang ditetapkan sebelumnya yang berdasarkan pertimbangan bahwa sumber data yang di peroleh berkaitan dengan materi yang diteliti, dalam hal ini sabjek hukum yang diteliti dijadikan sampel yaitu Kapolsek Jayapura Selatan dan Kanit Reskrim Polsek Jayapura Selatan (Winarni, 2021).

Dari data yang diperoleh baik dari data primer maupun data sekunder yang dikumpulkan, kemudian diseleksi dan diklasifikasikan kedalam bagian tertentu. Untuk seterusnya dianalisis secara kualitatif. Data kualitatif yang didapatkan kemudian dibandingkan dengan teori-teori ataupun peraturan-peraturan yang berlaku, yang akhirnya akan didapatkan pengetahuan tentang obyek yang diteliti yaitu Analisis Yuridis Kewenangan Diskresi Dan Pertanggung Jawaban Hukum Dalam Pelaksanaan Tugas Dan Fungsi Kepolisian (Studi Kasus Di Kepolisian Sektor Jayapura Selatan).

\section{Hasil dan Pembahasan}

A. Pelaksanaan dan Kewenangan dalam mengambil keputusan diskresi terhadap tindak pidana ringan di wilayah hukum kepolisian sektor Jayapura Selatan

Keputusan Diskresi sesungguhnya merupakan kelengkapan dari sistem pengaturan oleh hukum itu sendiri. Dengan kewenangan seperti itu, aparat Kepolisian seharusnya lebih jeli dalam penerapan hukum kepada masyarakat dengan melihat substansi perkara yang akan dilanjutkan proses penanganannya sehingga tidak melukai rasa keadilan masyarakat. Hal inilah yang kemudian harus dikaji, apakah pemberian kewenangan Diskresi yang telah diberikan Undangundang kepada pihak Kepolisian untuk memilah milah perkara yang akan diproses lebih lanjut telah dapat digunakan dengan baik oleh pihak Kepolisian sehingga dapat mencerminkan rasa keadilan dan profesionalisme Polri.

Secara yuridis dalam Undang-undang Republik Indonesia Nomor 2 Tahun 2002 tentang Kepolisian dan Undang undang Republik Indonesia Nomor 8 Tahun 1981 tentang KUHAP, dan Pasal 15 ayat (2) huruf k jo. Pasal 16 ayat (1) huruf 1 menyatakan: "Dalam rangka menyelenggarakan tugas di bidang proses pidana, Polri berwenang untuk mengadakan tindakan lain dalam bentuk tindakan penyelidikan dan penyidikan yang dilaksanakan sebagai (a) Tidak bertentangan dengan suatu aturan hukum, (b) Selaras dengan kewajiban hukum yang mengharuskan tindakan tersebut dilakukan, (c) Harus patut, masuk akal, dan termasuk dalam lingkungan jabatannya, (d) Pertimbangan yang layak berdasarkan keadaan yang memaksa dan (e) Menghormati hak asasi manusia".

Ada beberapa peristiwa dalam praktik, tindakan untuk mengesampingkan perkara dalam rangka menahan atau tidak melakukan penahanan terhadap tersangka/pelaku pelanggaran hukum atau menghentikan proses penyidikan, atau melakukan tindakan seketika bukanlah tindakan Diskresi individual petugas Kepolisian. Tindakan tersebut merupakan tindakan Diskresi birokrasi karena dalam pengambilan keputusan Diskresi berdasarkan atau berpedoman pada kebijaksanaan- 
kebijaksanaan pimpinan dalam organisasi dan hal tersebut telah dijadikan kesepakatan.

Pada beberapa kasus banyak penggunaan Diskresi Kepolisian dilakukan dalam bentuk penyelesaian perkara secara Restorative Justice, Restorative Justice merupakan suatu pendekatan yang lebih menitik-beratkan pada kondisi terciptanya keadilan dan keseimbangan bagi pelaku Tindak Pidana serta korbannya sendiri. Mekanisme tata acara dan peradilan pidana yang berfokus pada pemidanaan diubah menjadi proses dialog dan mediasi untuk menciptakan kesepakatan atas penyelesaian perkara pidana yang lebih adil dan seimbang bagi pihak korban dan pelaku (Barda Nawawi Arief, 2016).

Meskipun pada dasarnya aturan tertulis yang mengatur tentang peristiwa tersebut sudah sangat jelas tertulis dalam ketentuan undang-undang seperti tindak pidana pencurian ringan. Dalam perkara pencurian ringan, kebijakan Restorative Justice tentunya memiliki dasar hukum sebagai acuan aparat penegak hukum yaitu Peraturan Mahkamah Agung Republik Indonesia Nomor 2 Tahun 2012 tentang batasan tindak pidana ringan.

Didalam tafsiran Pasal 362 KUHP menentukan bahwa barang siapa mengambil barang sesuatu, yang seluruhnya atau sebagian kepunyaan orang lain, dengan maksud untuk dimiliki secara melawan hukum, diancam karena pencurian, dengan pidana penjara paling lama 5 (lima) tahun atau pidana denda paling banyak Rp.900.000,00- (sembilan ratus ribu rupiah). Sedangkan Pasal 364 KUHP menentukan bahwa perbuatan yang diterangkan dalam Pasal 362 dan Pasal 363 butir 4, begitu pun perbuatan yang diterangkan dalam Pasal 363 butir 5, apabila tidak dilakukan dalam sebuah rumah atau pekarangan tertutup yang ada rumahnya, jika harga barang yang dicuri tidak lebih dari Rp.25.000,00- (dua puluh lima rupiah), diancam karena pencurian ringan dengan pidana penjara paling lama 3 (tiga) bulan atau pidana denda paling banyak Rp.250,000,00- (dua ratus lima puluh rupiah).

Namun di dalam praktiknya apabila pencurian yang nilainya di bawah 2,5 juta rupiah perbuatan tersebut dapat dikatakan dengan tindak pidana ringan yang dapat di selesaikan secara Restorative Justice berdasarkan Peraturan Mahkamah Agung Republik Indonesia Nomor 2 Tahun 2012 (e) yaitu: "Bahwa Peraturan Mahkamah Agung ini sama sekali tidak bermaksud mengubah KUHP, Mahkamah Agung hanya melakukan penyesuaian nilai uang yang sudah sangat tidak sesuai dengan kondisi sekarang ini. Hal ini dimaksudkan memudahkan penegak hukum khususnya hakim, untuk memberikan keadilan terhadap perkara yang diadilinya".

Yang melatar belakangi lahirnya Peraturan Mahkamah Agung Republik Indonesia Nomor 2 Tahun 2012 ini, yakni upaya pemberian rasa keadilan bagi masyarakat terutama dalam penyelesaian perkara-perkara tindak pidana ringan (Tipiring). Secara teknis hukum yang dinamakan dengan Tipiring adalah suatu tindak pidana yang diancam dengan pidana penjara atau kurungan paling lama tiga bulan dan atau denda sebanyak-banyaknya tujuh ribu lima ratus rupiah dan 
penghinaan ringan. Oleh sebab itu subtansi Peraturan Mahkamah Agung Republik Indonesia Nomor 2 Tahun 2012 itu sebenarnya bukan pada nilai rupiahnya, tetapi pada tindak-tindak pidana yang ancaman hukumnya paling lama 3 bulan dan itu yang tidak perlu ditahan (Setiadi \& SH, 2017).

Kemudian dengan adanya penyesuaian denda dalam peraturan Mahkamah Agung Republik Indonesia Nomor 2 Tahun 2012 tentang penyesuaian batasan tindak pidana ringan dan jumlah denda dalam KUHP, diterbitkanlah nota kesepakatan bersama ketua mahkamah agung, menteri hukum dan hak asasi manusia, jaksa agung, kepala Kepolisian Negara Republik Indonesia Nomor 131/Kma/Skb/X/2012 Tahun 2012 tentang pelaksanaan penerapan penyesuaian batasan tindak pidana ringan dan jumlah denda, acara pemeriksaan cepat, serta penerapan keadilan (Setiadi \& SH, 2017).

Nota Kesepakatan tersebut menyebutkan bahwa Tipiring adalah tindak pidana yang diatur dalam Pasal 364, 373, 379, 384, 407 dan Pasal 482 Kitab UndangUndang Hukum Pidana ("KUHP") yang diancam dengan pidana penjara paling lama 3 (tiga) bulan atau denda 10.000 (sepuluh ribu) kali lipat dari denda. Peraturan Mahkamah Agung Republik Indonesia Nomor 2 Tahun 2012 juga harus dibarengi kemampuan penegak hukum untuk mengklasifikasi perkara yang bisa dilihat dari kehidupan sosial pelaku dan korban. Jangan sampai mencederai hak-hak korban, karena pada umumnya dalam suatu kasus hukum korban perlu dapat perlindungan hukum. Sebelum ditetapkannya Peraturan Mahkamah Agung ini, banyak tindak pidana yang meski hanya ber"obyek kecil tapi mendapat hukuman berat. Sementara tak jarang dijumpai pencurian berat tapi berujung pada pembebasan pelakunya.

Sebagaimana telah diketahui di atas pencurian yang nilai di bawah 2.5 Juta Rupiah dapat diselesaikan secara mediasi, dan tidak harus dipidanakan hal ini didasarkan Peraturan Mahkamah Agung Republik Indonesia Nomor 2 Tahun 2012 tentang penyesuaian tindak pidana ringan (Tipiring), Seperti contoh pengambilan keputusan Diskresi yang telah di tangani oleh Kepolisian Sektor Jayapura Selatan terhadap perkara tindak pidana pencurian ringan dan di selesaikan pula dengan cara Restorative Justice ialah kasus pencurian ringan berdasarkan Laporan Polisi Nomor: LP /B-187/ VI / 2019, dari Laporan tersebut dapat di uraikan bahwa pelapor merupakan anak warga kelurahan Ardipura yang dalam laporan tersebut melaporkan pencurian yang dilakukan temannya berupa objek benda tutup pentil variasi ban kendaraan sepeda motor Honda Vario. Dari laporan LP /B-187/VI/2019 tersebut pihak Kepolisian Sektor Jayapura Selatan tidak serta merta melakukan penindakan/penangkapan mengingat objek benda yang di curi nilainya di bawah 2.5 Juta Rupiah hal ini didasarkan Peraturan Mahkamah Agung Republik Indonesia Nomor: 2 Tahun 2012 tentang batasan tindak pidana ringan yang seharusnya di selesaikan secara restoratif (Restorative Justice), maka pihak Kepolisian Sektor Jayapura Selatan melalui Bhabinkamtibmas mengambil keputusan Diskresi dan melakukan mediasi dengan memanggil kedua belah pihak pelapor maupun terlapor serta melibatkan Yohanes selaku Tokoh masyarakat setempat untuk menyelasaikan perkara pencurian tutup pentil variasi ban kendaraan roda dua Honda Vario. 
Selanjutnya dari pertemuan kedua belah pihak yang telah di fasilitasi oleh Kepolisian Sektor Jayapura Selatan melalui Bhabinkamtibmas maka terjadi penyelesaian damai secara kekeluargaan mengingat Secara teknis Tokoh masyarakat setempat telah berkomitmen terlebih dahulu dengan Kepolisian Sektor Jayapura Selatan melalui Bhabinkamtibmas dalam bentuk hubungan apabila terdapat perkara ringan di wilayah hukumnya maka upaya penyelesaiannya secara kekeluargaan yang lebih di prioritaskan.

Selanjutnya menurut AKP (Ajun Komisaris Polisi) Yosias Pugu selaku Kapolsek Jayapura Selatan mengatakan: "Dalam pengambilan keputusan Diskresi yang telah di tangani oleh Kepolisian Sektor Jayapura Selatan terhadap perkara tindak pidana pencurian ringan berdasarkan Laporan Polisi Nomor: LP /B-187/ VI / 2019 tentu adanya kendala dari kedua pihak saat hendak di mediasikan dan di selesaikan secara Restorative Justice oleh Kepolisian Sektor Jayapura Selatan, salah satunya adanya dorongan (Intervensi) dari pihak keluarga korban yang merasa dirugikan untuk melanjutkan perkara pencurian tutup pentil ban kendaraan roda dua Honda Vario tersebut ke meja hijau (Persidangan), dengan adanya dorongan (Intervensi) dari pihak keluarga korban tersebut maka pihak Kepolisian Sektor Jayapura Selatan melihat ini sebagai penghambat berjalannya proses mediasi Penanganan Perkara Pencurian ringan yaitu Tutup Pentil Ban. Untuk itu pihak Kepolisian Sektor Jayapura Selatan mencoba melakukan dialog terhadap kedua belah pihak baik keluarga pelaku dan maupun keluarga korban" (Wawancara Bapak AKP Ajun Komisaris Polisi , 2012).

Selanjutnya menurut Bapak Samuel Johan selaku pihak keluarga (Paman) korban menjelaskan: "Pelaku tersebut memang suka bikin onar dan meresahkan masyarakat desa kami, apalagi pelaku sudah 2 kali ketahuan mencuri tutup pentil ban variasi honda vario milik keponakan saya, yang pertama kami maafkan, tetapi untuk yang kedua kalinya kami perkarakan. Meskipun harga dari tutup pentil ban variasi honda vario hanya 60 ribu rupiah Untuk itu pelaku harus di berikan efek jera agar tidak mengulangi perbuatan nya kembali dan penjara ialah tempat yang pantas membuat pelaku jera" (Wawancara Bapak Bapak Samuel Johan selaku pihak keluarga (Paman) korban, 2021).

Menurut Bapak Jhonson selaku pihak keluarga (Ayah) pelaku mengatakan: "Mengingat ini hanya kenakalan remaja kami meminta sekira nya keluarga korban untuk memberikan maaf kepada anak kami sebagai pelaku pencurian tutup pentil ban variasi honda vario, keluarga kami bersedia menganti kerugian harga barang yang telah di curi 10 (sepuluh) kali lipat dari harga yang sebelumnya, Akan tetapi keluarga korban bersedia mencabut laporan tersebut" (Wawancara Bapak Jhonson selaku pihak keluarga (Ayah) pelaku, 2021).

Berdasarkan wawancara tersebut penulis berpendapat bahwa komunikasi adalah faktor terpenting dalam usaha penyelesaian perkara dan mengambil keputusan Diskresi, apabila komunikasi terganggu maka hubungan dalam kordinasi tidak dapat berjalan dengan efektif. Pemulihan hubungan ini bisa didasarkan atas 
kesepakatan bersama antara korban dan pelaku. Pihak korban dapat menyampaikan mengenai kerugian yang dideritanya dan pelaku pun diberi kesempatan untuk menebusnya, melalui mekanisme ganti rugi, perdamaian, kerja sosial, maupun kesepakatan-kesepakatan lainnya. Hal ini menjadi penting Karena proses pemidanaan konvensional tidak memberikan ruang kepada pihak yang terlibat, dalam hal ini korban dan pelaku untuk berpartisipasi aktif dalam penyelesaian masalah mereka.

Penerapan dan pelaksanaan dari Diskresi itu sendiri sangat tergantung pada masalah yang dihadapi juga situasi dan kondisi yang ada di lapangan yang dialami oleh polisi tersebut. Sekalipun Diskresi Kepolisian bersifat situasional dan subejktif, namun Diskresi juga terdapat dasar hukumnya, sehingga bukan asalasalan saja. Dasar hukum tersebut dapat ditemukan dalam undang undang Kepolisian baik yang lama maupun yang terbaru yaitu Undang-Undang Republik Indonesia Nomor 2 tahun 2002 tentang Kepolisian, khususnya Pasal 18 yang memberikan kesempatan pada Polisi untuk menyelesaikan masalah di lapangan yang terkadang tidak bisa untuk diberlakukan aturan hukum secara kaku, Mengingat banyak tindak pidana yang meski hanya ber"obyek kecil tapi mendapat hukuman berat. Sementara tak jarang dijumpai pencurian berat tapi berujung pada pembebasan pelakunya.Selanjutnya mengenai penegakan hukum bukanlah sematamata berarti pelaksanaan perundang-undangan, walaupun dalam kenyataannya di Indonesia kecenderungannya adalah demikian, sehingga pengertian Law Enforcement begitu populer. Selain itu ada kecenderungan yang kuat untuk mengartikan penegakan hukum sebagai pelaksanaan keputusan-keputusan. Perlu dicatat bahwa pendapat yang agak sempit tersebut mempunyai kelemahankelemahan, apabila pelaksanaan perundang-undangan dan keputusan dan tindakan yang tidak tepat malah mengganggu kedamaian di dalam pergaulan hidup.

Menurut Sudikno Mertokusumo bahwa "Hukum berfungsi sebagai perlindungan kepentingan manusia. Agar kepentingan manusia terlindungi, hukum harus dilaksanakan. Pelaksanaan hukum dapat berlangsung secara normal, damai tetapi dapat terjadi juga karena pelanggaran hukum. Dalam hal ini hukum yang telah dilanggar itu harus ditegakkan, Melalui penegakan hukum inilah hukum menjadi kenyataan. Dalam menegakkan hukum ada tiga unsur yang selalu harus diperhatikan, yaitu kepastian hukum (Rechtssichherheit), kemanfaatan (Zweckmaasigkeit) dan keadilan (Gereichtigkeit) (Wawancara Bapak Jhonson selaku pihak keluarga (Ayah) pelaku, 2021).

Selanjutnya, penegakan hukum berkaitan erat dengan usaha menanamkan hukum di dalam masyarakat agar mengetahui, menghargai, mengakui dan mentaati hukum, reaksi masyarakat yang didasarkan pada sistem nilai-nilai yang berlaku dan jangka waktu menanamkan hukum. Sementara itu, mengenai tolak ukur dari efektivitas hukum, dikemukakan oleh Soerjono Soekanto bahwa masalah pokok penegakan hukum sebenarnya terletak pada faktor-faktor yang mempengaruhi penegakan hukum. Faktor-faktor tersebut disamping merupakan esensi dari penegakan hukum, juga merupakan tolok ukur daripada efektivitas penegakan 
hukum. Selanjutnya ia menjelaskan mengenai faktor-faktor yang mempengaruhi penegakan hukum, sebagai Faktor hukumnya sendiri, yang didalam tulisan ini akan dibatasi pada undang-undang saja. (1) Faktor penegak hukum, yakni pihak-pihak yang membentuk maupun menerapkan hukum, (2) Faktor sarana atau fasilitas yang mendukung penegakan hukum,(3) Faktor masyarakat, yakni lingkungan dimana hukum tersebut berlaku atau diterapkan, (4) Faktor kebudayaan, yakni sebagai hasil karya, cipta, dan (5) rasa yang didasarkan pada karsa manusia di dalam pergaulan hidup (Soerjono Soekanto, 2019) Kelima faktor tersebut saling berkaitan dengan eratnya, oleh karena merupakan esensi dari penegakan hukum, juga merupakan tolak ukur dari pada efektivitas penegakan hukum. Dengan demikian, maka kelima faktor tersebut akan dibahas disini, dengan cara mengetengahkan contoh-contoh yang diambil dari kehidupan masyarakat Indonesia.

Lalu menurut Purbacaraka dan Soerjono Soekanto Undang-Undang dalam arti material adalah peraturan tertulis yang berlaku umum dan dibuat oleh Penguasa Pusat maupun Daerah yang sah. Mengenai berlakunya Undang-Undang tersebut, terdapat beberapa asas yang tujuannya adalah agar Undang-Undang tersebut mempunyai dampak yang positif. Asas-asas tersebut antara lain Undang-Undang tidak berlaku surut, Undang-Undang yng dibuat oleh penguasa yang lebih tinggi, Mempunyai kedudukan yang lebih tinggi pula, Undang-Undang yang bersifat khusus menyampingkan Undang-Undang yang bersifat umum, apabila pembuatnya sama, Undang-Undang yang berlaku belakangan, membatalkan Undang-Undang yang berlaku terdahulu, Undang-Undang tidak dapat diganggu gugat, UndangUndang merupakan suatu sarana untuk mencapai kesejahteraan spiritual dan materiel bagi masyarakat maupun pribadi, melalui pelestaian ataupun pembaharuan (inovasi) (Wawancara Bapak Jhonson selaku pihak keluarga (Ayah) pelaku, 2021).

B. Pertanggung jawaban hukum dalam megambil keputusan diskresi terhadap tindak pidana pencurian ringan di wilayah hukum kepolisian sektor Jayapura Selatan

Keamanan suatu negara adalah hal yang sangat penting dalam keberhasilan pelaksanaan pembangunan nasional. Jika suatu negara berada dalam situasi aman, maka selanjutnya yang didambakan oleh masyarakat dan pemerintah adalah suatu kehidupan yang bahagia, sejahtera, adil dan makmur dari para warga negaranya, Faktor keamanan tersebut merupakan salah satu tanggung jawab dari Polri. Sebagai bagian dari proses penyelenggara negara, institusi Kepolisian pun terikat kepada aturan-aturan Hukum dan prosedur-prosedur tertentu, serta dikontrol dan bertanggung jawab kepada hukum. begitu pula dengan keputusan Diskresi yang di ambil oleh anggota Polri, Keputusan dari Diskresi itu sendiri sangat tergantung pada masalah yang dihadapi juga situasi dan kondisi yang ada di lapangan yang dialami oleh Polisi tersebut.

Sekalipun Diskresi Kepolisian bersifat situasional dan subejktif, namun Diskresi juga terdapat dasar hukumnya untuk dapat dipertanggungjawabkan, sehingga bukan terkesan asal-asalan saja. Dasar hukum tersebut dapat ditemukan 
dalam undang undang Kepolisian baik yang lama maupun yang terbaru yaitu Undang-Undang Republik Indonesia Nomor 2 tahun 2002 tentang Kepolisian, khususnya Pasal 18 yang memberikan kesempatan pada Polisi untuk menyelesaikan masalah di lapangan yang terkadang tidak bisa untuk diberlakukan aturan hukum secara kaku atau bahkan belum terdapat pengaturannya sama sekali. Tentunya hal tersebut memerlukan suatu kebijaksanaan dari Polisi itu sendiri, sekalipun UndangUndang memberikan kesempatan bagi polisi untuk melakukan Diskresi.

Persoalan hukum di masyarakat dapat diselesaikan berdasar hukum tidak tertulis yang berupa hukum adat, yang berpedoman pada adat kebiasaan yang ada di masyarakat yang sesuai atau tidak bertentangan dengan hukum positif yang ada. Tujuannya untuk mempertahankan keamanan dan ketertiban di dalam masyarakat serta tidak merugikan hak-hak orang lain. Begitu pula penyelesaian perkara atau mengenyampingkan perkara-perkara pidana yang ringan biasanya ditempuh berdasarkan kebiasaan praktek atau hukum tidak tertulis karena apabila dipaksakan berlakunya hukum pidana justru akan menimbulkan permasalahan baru, sehingga adat kebiasaanlah yang dipakai dalam menyelesaikan suatu perkara, karena bagaimanapun juga hal itu dirasa lebih praktis dan lebih murah daripada diselesaikan lewat sistem peradilan pidana. Misalnya saja ditempuh dengan upaya kekeluargaan yang dirasa bisa menyelesaikan masalah tanpa menjadikan hubungan yang ada di masyarakat tadi menjadi renggang atau pecah. Hal inilah yang menjadi alasan mengapa hukum adat yang berlaku di masyarakat juga mempunyai peranan di dalam pelaksanaan Diskresi oleh polisi.

Dalam kasus perkara tindak pidana ringan yang terjadi Di Wilayah Hukum Kepolisian Sektor Jayapura Selatan yang dimana kasus tersebut Polisi telah Megambil Keputusan Diskresi Terhadap Tindak Pidana Pencurian Ringan berdasarkan Laporan Polisi Nomor: LP /B-187/ VI / 2019 tentunya penggunaan kewenangan dan tanggungjawab hukumnya harus memiliki landasan.

Menurut Kanit Reskrim Polsek Jayapura Selatan menjelaskan: "Penggunaan kewenangan Diskresi yang dilakukan oleh Kepolisian Sektor Jayapura Selatan secara legal saat menjalankan tanggungjawabnya untuk memelihara keamanan dan ketertiban umum masih juga menimbulkan persoalan yang mengurangi Legitimasi Polisi. Ketidakselarasan antara teori dan praktik membuktikan bahwa pekerjaan Kepolisian tidak mengandung unsur diskriminasi, maka kesimpulannya pada saat penerapan Diskresi, kemungkinan di dalamnya terjadi diskriminasi yang disebabkan oleh intervensi dari beberapa pihak yang berkonflik itu sendiri"

Peran Polisi secara umum dikenal sebagai pemelihara Kamtibmas juga sebagai aparat penegak hukum dalam proses pidana. Polisi adalah aparat penegak hukum jalanan yang langsung berhadapan dengan masyarakat dan penjahat. Dalam Pasal 2 Undang-Undang Republik Indonesia Nomor 2 Tahun 2002 tentang Kepolisian Republik Indonesia yaitu "Fungsi Kepolisian adalah salah satu fungsi pemerintahan negara di bidang pemeliharaan keamanan dan ketertiban masyarakat, penegakan hukum, perlindungan, pengayoman, dan pelayanan kepada masyarakat”. 
Pasal 4 Undang-Undang Republik Indonesia Nomor 2 Tahun 2002 juga menegaskan: "Kepolisian Negara Republik Indonesia bertujuan untuk mewujudkan keamanan dalam negeri yang meliputi terpeliharanya keamanan dan ketertiban masyarakat, tertib, dan tegaknya hukum, terselenggaranya perlindungan, pengayoman, dan pelayanan kepada masyarakat, serta terbinanya ketentraman masyarakat dengan menjunjung tinggi hak asasi manusia". Dalam Pasal 18 ayat (1) bahwa "Untuk kepentingan umum pejabat Kepolisian Negara Republik Indonesia dalam melaksanakan tugas dan wewenangnya dapat bertindak menurut penilaiannya sendiri". Dalam Pasal 18 ayat (2) bahwa "Pelaksanaan ketentuan sebagaimana dimaksud dalam ayat (1) hanya dapat dilakukan dalam keadaan yang sangat perlu dengan memperhatikan peraturan perundang-undangan serta Kode Etik Profesi Kepolisian Negara Indonesia".

Dalam Pasal 18 ayat (1), Untuk kepentingan umum, pejabat Kepolisian Negara Republik Indonesia dalam melaksanakan tugas dan wewenangnya dapat bertindak menurut penilaiannya sendiri. Ayat (2) Pelaksanaan ketentuan sebagaimana dimaksud dalam ayat (1) hanya dapat dilakukan dalam keadaan yang sangat perlu dengan memperhatikan peraturan perundang-undangan, serta Kode Etik Profesi Kepolisian Negara Republik Indonesia.

Undang-Undang Republik Indonesia Nomor 8 tahun 1981 tentang Kitab undang-undang Hukum Acara Pidana (KUHAP), diskresi yang berhubungan dengan penyelidikan dan penyidikan tindak pidana termasuk penyidikan pelanggaran tindak pidana lalu lintas yang dalam hal ini menunjuk adanya tindakan lain berdasarkan hukum yang dapat dipertanggung jawabkan antara lain Dalam Pasal 7 ayat $1 \mathrm{j}$ KUHAP, yang memberikan wewenang kepada penyidik yang karena kewajibannya dapat melakukan tindakan apa saja menurut hukum yang bertanggung jawab. Adapun " tindakan lain" ini dibatasi dengan syarat Tidak bertentangan dengan suatu aturan hukum, Selaras dengan kewajiban hukum yang mengharuskan dilakukannya tindakan jabatan, Tindakan itu harus patut dan masuk akal dan termasuk dalam lingkungan jabatanya Atas pertimbangan yang layak berdasarkan keadaan memaksa.

Penegakan hukum merupakan suatu hal yang mutlak harus dilakukan karena dengan penegakan hukum dapatlah diwujudkan tujuan dan fungsi hukum ditengah masyarakat. Melalui penegakan hukum, dapatlah pula diwujudkan suasana kondusif, dalam arti terwujudnya suasana keadaan yang serasi, selaras dan seimbang dalam semua segi aspek hidup dan kehidupan masyarakat, maka hukum hanyalah merupakan simbol belaka yang tidaklah mungkin dapat menegakkan dirinya sendiri tanpa usaha konkrit dari manusia (Soerjono Soekanto, 2019). Masalah pokok penegakan hukum sebenarnya terletak pada faktor-faktor yang mungkin mempengaruhinya. Faktor-faktor tersebut mempunyai arti yang netral, sehingga dampak positif atau negatifnya terletak pada isi-isi pada faktor-faktor tersebut. Faktor-faktor tersebut, adalah sebagai berikut: 
1. Faktor hukumnya sendiri, yang didalam tulisan ini akan dibatasi pada UndangUndang saja;

2. Faktor penegak hukum, yakni pihak-pihak yang membentuk maupun menrapkan hukum;

3. Faktor sarana atau fasilitas yang mendukung penegakan hukum;

4. Faktor masyarakat, yakni lingkungan dimana hukum tersebut berlaku atau diterapkan;

5. Faktor kebudayaan, yakni sebagai hasil karya, cipta, dan rasa yang didasarkan pada karsa manusia di dalam pergaulan hidup (Soerjono Soekanto, 2019).

Kelima faktor tersebut saling berkaitan dengan eratnya, oleh karena merupakan esensi dari penegakan hukum, juga merupakan tolak ukur dari pada efektivitas penegakan hukum. Dengan demikian, maka kelima faktor tersebut akan dibahas disini, dengan cara mengetengahkan contoh-contoh yang diambil dari kehidupan masyarakat Indonesia.

1. Undang-Undang

Menurut Purbacaraka dan Soerjono Soekanto Undang-Undang dalam arti material adalah peraturan tertulis yang berlaku umum dan dibuat oleh Penguasa Pusat maupun Daerah yang sah. Mengenai berlakunya Undang-Undang tersebut, terdapat beberapa asas yang tujuannya adalah agar Undang-Undang tersebut mempunyai dampak yang positif. Asas-asas tersebut antara lain:

a. Undang-Undang tidak berlaku surut;

b. Undang-Undang yng dibuat oleh penguasa yang lebih tinggi;

c. Mempunyai kedudukan yang lebih tinggi pula;

d. Undang-Undang yang bersifat khusus menyampingkan Undang-Undang yang bersifat umum, apabila pembuatnya sama;

e. Undang-Undang yang berlaku belakangan, membatalkan Undang-Undang yang berlaku terdahulu;

f. Undang-Undang tidak dapat diganggu guat;

g. Undang-Undang merupakan suatu sarana untuk mencapai kesejahteraan spiritual dan materiel bagi masyarakat maupun pribadi, melalui pelestaian ataupun pembaharuan (inovasi) (Setiadi \& SH, 2017).

Gangguan terhadap penegakkan hukum yang berasal dari Undang-Undang mungkin disebabkan, karena:

a. Tidak diikuti asas-asas berlakunya Undang-Undang,

b. Belum adanya peraturan pelaksanaan yang sanat dibutuhkan untuk menerapkan Undang-Undang,

c. Ketidakjelasan arti kata-kata di dalam undang-undang yang mengakibatkan kesimpangsiuran di dalam penafsiran serta penerapannya (Soerjono Soekanto, 2019).

2. Penegak Hukum

Penegak hukum merupakan golongan panutan dalam masyarakat, yang hendaknya mempunyai kemampuan-kemampuan tertentu sesuai dengan aspirasi masyarakat. Mereka harus dapat berkomunikasi dan mendapat pengertian dari 
golongan sasaran, disamping mampu menjalankan atau membawakan peranan yang dapat diterima oleh mereka. Pembahasan mengenai penegak hukum sebenarnya lebih banyak tertuju pada diskresi. Sebagaimana dikatakan dimuka, maka diskresi menyangkut pengambilan putusan yang tidak sangat terikat oleh hukum, di mana penilaian pribadi juga memegang peranan (Soerjono Soekanto, 2019). Di dalam penegakan hukum diskresi sangat penting, oleh karena :

1) Tidak ada perundang-undangan yang sedemikian lengkapnya, sehingga dapat mengatur semua perilaku manusia;

2) Adanya kelambat-lambatan untuk menyesuaikan perundang-undangan dengan perkembangan-perkembangan di dalam masyrakat;

3) Kurangnya biaya untuk menerapkan perundang-undangan sebagaimana yang dikehendaki oleh pembentuk Undang-Undang;

4) Adanya kasus-kasus individual yang memerlukan penanganan secara khusus.

5) Ada beberapa halangan yang mungkin dijumpai pada penerapan peranan yang seharusnya dari golngan sasaran atau penegak hukum, Halangan-halangan tersebut, adalah:

a. Keterbatasan kemampuan untuk menempatkan diri dalam peranan pihak lain dengan siapa dia berinteraksi;

b. Tingkat aspirasi yang relatif belum tinggi;

c. Kegairahan yang sangat terbatas untuk memikirkan masa depan, sehingga sulit sekali untuk membuat proyeksi;

d. Belum ada kemampuan untuk menunda pemuasan suatu kebutuhan tertentu, terutama kebutuhan material;

e. Kurangnya daya inovatif yang sebenarnya merupakan pasangan konservatisme (Soerjono Soekanto, 2019).

Halangan-halangan tersebut dapat diatasi dengan membiasakan diri dengan sikap-sikap, sebagai berikut:

a. Sikap yang terbuka terhadap pengalaman maupun penemuan baru. Artinya, sebanyak mungkin menghilangkan prasangka terhadap hal-hal yang baru atas berasal dari luar, sebelum dicoba manfaatnya;

b. Senantiasa siap untuk menerima perubahan setelah menilai kekurangan yang ada pada saat itu;

c. Peka terhadap masalah-masalah yang terjadi di sekitarnya dengan dilandasi suatu kesadaran, bahwa persoalan-persoalan tersebut berkaitan dengan dirinya;

d. Senantiasa mempunyai informasi yang selengkap mungkin mengenai pendiriannya;

e. Orientasi ke masa kini dan masa depan yang sebenarnya merupakan suatu urutan;

f.Menyadari akan potensi yang ada dalam dirinya, dan percaya bahwa potesipotensi tersebut akan dapat dikembangkan;

g. Berpegang pada suatu perencanaan dan tidak pasrah pada nasib (yang buruk); 
h. Percaya pada kemampuan ilmu pengetahuan dan teknologi di dalam meningkatkan kesejahteraan umat manusia;

i. Menyadari dan menghormati hak, kewajiban, maupun kehormatan diri sendiri dan pihak-pihak lain;

j. Berpegang teguh pada keputusan-keputusan yang diambil atas dasar penalaran dan perhitingan yang mantap (Soerjono Soekanto, 2019).

3. Faktor Sarana atau Fasilitas

Tanpa adanya sarana atau fasilitas tertentu, maka tidak mungkin penegakan hukum akan berjalan dengan lancar. Sarana atau fasilitas tersebut antara lain, mencakup tenaga manusia yang berpendidikan dan trampil, organisasi yang baik, peralatan yang memadai, keuangan yang cukup, dan seterusnya. Sarana atau fasilitas mempunyai peran yang sangat penting dalam penegakan hukum. Tanpa adanya sarana atau fasilitas tersebut, tidak akan mungkin penegak hukum menyerasikan peranan yang seharusnya dengan peranan yang actual (Jimly Asshiddiqie, 2015). Khususnya untuk sarana atau fasilitas tesebut, sebaiknya dianut jalan pikiran, sebagai berikut:

a. Yang tidak ada-diadakan yang baru betul;

b. Yang rusak atau salah-diperbaiki atau dibetulkan;

c. Yang kurang-ditambah;

d. Yang macet-dilancarkan;

e. Yang mundur atau merosot-dimajukan atau ditingkatkan.

4. Faktor Masyarakat

Penegakan hukum berasal dari masyarakat, dan bertujuan untuk mencapai kedamaian dalam masyarakat. Oleh karena itu, dipandang dari sudut tertentu, maka masyarakat dapat mempengaruhi penegakan hukum tersebut. Masyarakat Indonesia mempunyai kecendrungan yang besar untuk mengartikan hukum dan bahkan mengidentifikasikannya dengan petugas (dalam hal ini penegak hukum sebagai pribadi). Salah satu akibatnya adalah, bahwa baik buruknya hukum senantiasa dikaitkan dengan pola perilaku penegak hukum tersebut, yang menurut pendapatnya merupakan pencerminan dari hukum sebagai sturktur maupun proses.

Faktor-faktor yang menyebabkan masyarakat mematuhi hukum setidaktidaknya dapat dikembalikan pada faktor-faktor sebagai berikut :

\section{a. Compliance}

Orang menaati hukum karena takut terkena hukuman. Ketaatan sebagai pemenuhan suatu penerimaan terang yang dibujuk oleh harapan penghargaan dan suatu usaha kuat untuk menghindari kemungkinan hukuman, bukan karena keinginan kuat untuk menaati hukum.

\section{b. Identification}

Ketaatan kepada suatu aturan karena takut hubungan baiknya dngan seseorang menjadi rusak.

c. Internalization 
Ketaatan pada suatu aturan karena ia benar-benar merasa bahwa aturan itu sesuai dengan nilai instrinsik yang dianutnya (Romli Atmasasmita, 2011).

Akan tetapi, saat ini posisi masyarakat untuk sadar akan hukum masih sangat kurang. Paradigma yang digunakan oleh masyarakat untuk taat pada hukum adalah obyek sanksinya. Masyarakat akan menilai hukum dari sanksi yang diberikan jika melanggar. Faktor sanksi ini sangat berpengaruh pada bagaimana tingkat kesadaran seseorang untuk patuh pada hukum. Adapun indikator-indikator yang mempengaruhi kesadaran hukum suatu masyarakat yakni :

a. Pengetahuan hukum yang dimaksud adalah pengetahuan akan peraturanperaturan hukum (law awareness). Mustahil masyarakat bisa memahami, bersikap ataupun berperilaku yang berujung akan kesadaran hukum sebagaimana yang dikehendaki dalam hukum (aturan-aturan) jika pengetahuan akan hukum tidak ada.

b. Pemahaman hukum adalah hal penting setelah masyarakat mengetahui hukum itu sendiri karena sikap dan perilaku sangat bergantung dari seberapa pahamnya masyarakat terhadap hukum.

c. Sikap Bentuk evaluasi dari pengetahuan dan pemahaman akan hukum terlihat dari sikap masyarakat terhadap hukum itu sendiri. Apakah masyarakat akan mendukung dengan menunjukan sikap positif ataukah mayarakat akan apatis sehingga menimbulkan sikap negatif terhadap keberadaan hukum. Yang menjadi landasannya adalah seberapa tahu dan seberapa paham masyarakat akan hukum.

d. Perilaku hukum Reaksi atau respon masyarakat terhadap hukum terlihat dari seperti apa pola perilaku hukum (legal behavior) yang ditunjukan. Inilah bentuk evaluasi umum sebagai bentuk konkritisasi akan pengetahuan, pemahaman dan sikap masyarakat terhadap hukum.

Kesadaran hukum akan terwujud apabila indikator-indikator di atas mampu diaktualisasikan dan diselaraskan.

5. Faktor Kebudayaan

Kebudayaan (system) hukum pada dasarnya mencakup nilai-nilai yang mendasari hukum yang berlaku, nilai-nilai yang merupakan konsepsi abstrak mengenai apa yang dianggap baik (sehingga dianuti) dan apa yang dianggap buruk (sehingga dihindari). Nilai-nilai tersebut, lazimnya merupakan pasangan nilai-nilai yang mencerinkan dua keadaan ekstrin yang harus diserasikan. Pasangan nilai yang berperan dalam hukum, adalah sebagai berikut :

a. Nilai ketertiban dan nilai ketentraman;

b. Nilai jasmani/kebendaan dan nilai rohani/keakhlakan;

c. Nilai kelanggengan/konservatisme dan nilai kebaruan/inovatisme.

Dalam rangka penegakan aturan hukum diperlukan pula pembaharuan atau pembentukan peraturan hukum yang baru. Oleh karena itu terdapat empat hal penting yang perlu mendapat perhatian, yakni: perlunya pembentukan peraturan baru, perlunya sosialisasi hukum kepada masyarakat, perlunya penegakan aturan 
hukum dan yang tidak kalah pentingnya untuk mendukung seluruh kegiatan tersebut adalah perlunya administrasi hukum yang yang efektif dan efisien serta akuntabel.

Secara konkrit dalam kehidupan masyarakat sehari-hari. Inilah yang dimaksud penegakan hukum itu. "Negara Indonesia adalah Negara Hukum", dalam Undang-Undang Dasar Tahun 1945 Pasal 1 Ayat 3 amandemen ketiga. Dalam penjelasan Undang-Undang Dasar Tahun 1945 mengenai sistem pemerintahan negara disebutkan bahwa"Negara Indonesia berdasarkan atas hukum (Rechtsstaat), tidak berdasarkan atas kekuasaan belaka (Machtsstaat)". Prinsip dasar yang dianut dalam hukum dasar tersebut memberikan gambaran hukum menjadi landasan kehidupan masyarakat. Atau dengan kata lain yang ingin ditegakkan dalam Negara ini adalah supremasi hukum bukan supremasi kekuasaan (Romli Atmasasmita, 2011).

Menurut Jimly Asshiddiqie, "Penegakan hukum adalah proses dilakukannya upaya untuk tegaknya atau berfungsinya norma-norma hukum secara nyata sebagai pedoman perilaku dalam lalu lintas atau hubungan-hubungan hukum dalam kehidupan bermasyarakat dan bernegara" (Jimly Asshiddiqie, 2015). Penegakan hukum suatu proses, pada hakikatnya merupakan penerapan diskresi yang menyangkut membuat keputusan yang tidak secara ketat diatur oleh kaidah hukum, akan tetapi mempunyai unsur penilaian pribadi. Dengan mengutip pendapat Roscoe Pound, maka LaFavre menyatakan, bahwa pada hakikatnya diskresi berada di antara hukum dan moral (etika dalam arti sempit). Gangguan terhadap penegakan hukum mungkin terjadi, apabila ada ketidakserasian antara “tritunggal" nilai, kaidah dalam pola perilaku (Jimly Asshiddiqie, 2015).

Penegakan hukum bukanlah semata-mata berarti pelaksanaan perundangundangan, walaupun didalam kenyataan di Indonesia kecenderungannya adalah demikian, sehingga pengertian law enforcement begitu popular. Selain itu, ada kecenderungan yang kuat untuk mengartikan penegakan hukum sebagai pelaksanaan keputusan-keputusan hakim. Perlu dicatat, bahwa pendapat-pendapat yang agak sempit tersebut mempunyai kelemahan-kelemahan, apabila pelaksanaan perundang-undangan atau keputusan-keputusan hakim tersbut malahan mengganggu kedamaian di dalam pergaulan hidup. Selain itu, penegakan hukum juga dapat ditinjau dari sudut subyek dan sudut obyek penegakan hukum (Romli Atmasasmita, 2011). Sudut subyek penegakan hukum dapat dibedakan menjadi dua, yakni dalam arti sempit dan dalam arti luas. Dalam arti sempit, dari segi subjeknya itu, penegakan hukum itu hanya diartikan sebagai upaya aparatur penegakan hukum tertentu untuk menjamin dan memastikan bahwa suatu aturan hukum berjalan sebagaimana seharusnya. Dalam memastikan tegaknya hukum itu, apabila diperlukan, aparatur penegak hukum itu diperkenankan untuk menggunakan daya paksa. Dalam arti luas, proses penegakan hukum itu melibatkan semua subjek hukum dalam setiap hubungan hukum. Siapa saja yang menjalankan aturan normatif atau melakukan sesuatu atau tidak melakukan 
sesuatu dengan mendasarkan diri pada norma aturan hukum yang berlaku, berarti dia menjalankan atau menegakkan aturan hukum.

Pengertian penegakan hukum itu ditinjau dari sudut objeknya, yaitu dari segi hukumnya. Dalam hal ini, pengertiannya juga mencakup makna yang luas dan sempit. Dalam arti luas, penegakan hukum itu mencakup pula nilai-nilai keadilan yang terkandung di dalamnya bunyi aturan formal maupun nilai-nilai keadilan yang hidup dalam masyarakat. Tetapi, dalam arti sempit, penegakan hukum itu hanya menyangkut penegakan peraturan yang formal dan tertulis saja.

Dengan uraian di atas jelaslah kiranya bahwa yang dimaksud dengan penegakan hukum itu kurang lebih merupakan upaya yang dilakukan untuk menjadikan hukum, baik dalam arti formil yang sempit maupun dalam arti materiel yang luas, sebagai pedoman perilaku dalam setiap perbuatan hukum, baik oleh para subjek hukum yang bersangkutan maupun oleh aparatur penegakan hukum yang resmi diberi tugas dan kewenangan oleh undang-undang untuk menjamin berfungsinya norma-norma hukum yang berlaku dalam kehidupan bermasyarakat dan bernegara. Hukum berfungsi sebagai perlindungan kepentingan manusia. Agar kepentingan manusia terlindungi, hukum harus dilaksanakan. Pelaksanaan hukum dapat berlangsung secara normal, damai, tetapi dapat terjadi juga karena pelanggaran hukum. Dalam hal ini hukum yang dilanggar itu harus ditegakkan. Melalui penegakan hukum inilah hukum itu terjadi kenyataan. Dalam menegakkan hukum ada tiga unsur yang selalu harus diperhatikan, yaitu: kepastian hukum (rechtssicherheit), kemanfaatan (zweckmassigkeit) dan keadilan (gerechtigkeit) (Soerjono Soekanto, 2019).

Secara konsepsional, maka inti dari penegakan hukum terletak pada kegiatan menyerasikan hubungan nilai-nilai yang terjabarkan di dalam kaidahkaidah yang mantap dan mengejawantah dan sikap tindak sebagai rangkaian penjabaran nilai tahap akhir, untuk menciptakan, memelihara dan mempertahankan kedamaian pergaulan hidup.

\section{Kesimpulan}

Pengambilan keputusan Diskresi yang telah di tangani oleh Kepolisian Sektor Jayapura Selatan terhadap perkara tindak pidana pencurian ringan dan di selesaikan pula dengan cara Restorative Justice ialah kasus pencurian ringan berdasarkan Laporan Polisi Nomor: LP /B-187/ VI / 2019,Dari laporan LP /B-187/VI/2019 tersebut pihak Kepolisian Sektor Jayapura Selatan tidak serta merta melakukan penindakan/penangkapan mengingat objek benda yang di curi nilainya di bawah 2.5 Juta Rupiah hal ini didasarkan Peraturan Mahkamah Agung Republik Indonesia Nomor: 2 Tahun 2012 tentang batasan tindak pidana ringan yang seharusnya di selesaikan secara restoratif (Restorative Justice), maka pihak Kepolisian Sektor Jayapura Selatan melalui Bhabinkamtibmas mengambil keputusan Diskresi dan melakukan mediasi dengan memanggil kedua belah pihak pelapor maupun terlapor serta melibatkan Yohanes selaku Tokoh masyarakat setempat untuk menyelesaikan perkara pencurian 
tutup pentil variasi ban kendaraan roda dua Honda Vario. Selanjutnya dari pertemuan kedua belah pihak yang telah di fasilitasi oleh Kepolisian Sektor Jayapura Selatan melalui Bhabinkamtibmas maka terjadi penyelesaian damai secara kekeluargaan mengingat Secara teknis Tokoh masyarakat setempat telah berkomitmen terlebih dahulu dengan Kepolisian Sektor Jayapura Selatan melalui Bhabinkamtibmas dalam bentuk hubungan apabila terdapat perkara ringan di wilayah hukumnya maka upaya penyelesaiannya secara kekeluargaan yang lebih di prioritaskan.

Sebagai bagian dari proses penyelenggara negara, Kepolisian Sektor Jayapura Selatan pun terikat kepada aturan-aturan Hukum dan prosedur-prosedur tertentu, serta dikontrol dan bertanggung jawab kepada hukum. begitu pula dengan keputusan Diskresi yang di ambil, Keputusan dari Diskresi itu sendiri sangat tergantung pada masalah yang dihadapi juga situasi dan kondisi yang ada di lapangan yang dialami oleh Kepolisian Sektor Jayapura Selatan tersebut. Sekalipun Diskresi Kepolisian bersifat situasional dan subejktif, namun Diskresi juga terdapat dasar hukumnya untuk dapat dipertanggungjawabkan, sehingga bukan terkesan asal-asalan saja. Dasar hukum tersebut dapat ditemukan dalam undang undang Kepolisian baik yang lama maupun yang terbaru yaitu Undang-Undang Republik Indonesia Nomor 2 tahun 2002 tentang Kepolisian, khususnya Pasal 18 yang memberikan kesempatan pada Polisi untuk menyelesaikan masalah di lapangan yang terkadang tidak bisa untuk diberlakukan aturan hukum secara kaku atau bahkan belum terdapat pengaturannya sama sekali. Tentunya hal tersebut memerlukan suatu kebijaksanaan dari Polisi itu sendiri, sekalipun Undang-Undang memberikan kesempatan bagi polisi untuk melakukan Diskresi. 
Analisis Yuridis Kewenangan Diskresi dan Pertanggung Jawaban Hukum dalam

Pelaksanaan Tugas dan Fungsi Kepolisian

\section{BIBLIOGRAFI}

Agung, Dwi Hartono. (2012). Tinjauan Diskresi Kepolisian Dalam Pelaksanaan Tugas Penyidikan Tindak Pidana Menurut Undang-Undang No. 2 Tahun 2002 Tentang Kepolisian. Faculty Of Law.Repositori UPN Jatim. Google Scholar

Atmodjo, Bambang Dwi. (2015). Optimalisasi Penegakan Hukum Disiplin Bagi Anggota Polri Dalam Pelaksanaan Sidang Disiplin Guna Mewujudkan Polri Yang Disiplin. Universitas Pembangunan Nasional Veteran Jakarta. Repositori UPN Jatim. Google Scholar

Barda Nawawi Arief, S. H. (2016). Bunga rampai kebijakan hukum pidana. Prenada Media.Jakarta. Google Schoolar

Cahyaningtyas, Elisa Tri. (2015). Pembuatan Sistem Informasi Pertanahan Menggunakan Bahasa Pemrograman C\# Dan Mapwindow Gis. itn malang.Google Scholar

Fardani, Tasya Nugrahini. (2021). Analisis putusan nomor 138/Pid. sus/2019/PN. BKS tentang vonis bebas pelaku tindak pidana pemilu politik uang dihubungkan dengan Pasal 523 ayat (1) juncto Pasal 280 ayat (1) Undang-Undang Republik Indonesia nomor 7 tahun 2017 tentang Pemilihan Umum. UIN Sunan Gunung Djati Bandung.Google Schoolar

Hambali, Azwad Rachmat. (2020). Penegakan Hukum Melalui Pendekatan Restorative Justice Penyelesaian Perkara Tindak Pidana. Kalabbirang Law Journal, 2(1), 6977.Google Scholar

Jimly Asshiddiqie. (2015). Penguatan Sistem Pemerintahan Dan Peradilan (Sinar Grafika, Ed.). Jakarta.Google Scholar

Romli Atmasasmita. (2011). Reformasi Hukum, Hak Asasi Manusia \& Penegakan Hukum. Bandung;Mandar Maju.Google Scholar

Setiadi, H. Edi, \& SH, M. H. (2017). Sistem Peradilan Pidana Terpadu dan Sistem Penegakan Hukum di Indonesia. Prenada Media.Google Scholar

Sitinjak, Neovaldo. (2021). Analisis Yuridis Kewenangan Diskresi dan Pertanggung Jawaban Hukum dalam Pelaksanaan Tugas dan Fungsi Kepolisian (Studi Kasus Di Kepolisian Sektor Jayapura Selatan). Universitas Tarumanagara. Repository Untar. Google Scholar

Soerjono Soekanto. (2019). Pengantar Penelitian Hukum. Jakarta: UI Press.Google Scholar

Syaifullah, Mulida Hayati. (2019). Penegakan Hukum Pelanggaran Disiplin Anggota Polri Di Mapolda Kalimantan Tengah. Jurnal Ilmu Hukum Tambun Bungai, 4(2).Google Scholar 
Neovaldo Sitinjak

Wawancara Bapak AKP (Ajun Komisaris Polisi). (2012). Yosias Pugu Selaku Kapolsek Jayapura Selatan.

Wawancara Bapak Bapak Samuel Johan selaku pihak keluarga (Paman) korban. (2021). Pada Selasa 19 Januari 2021 Pukul 14.30 Wib.

Wawancara Bapak Jhonson selaku pihak keluarga (Ayah) pelaku. (2021). Wawancara Bapak Jhonson selaku pihak keluarga (Ayah) pelaku.

Winarni, Endang Widi. (2021). Teori dan Praktik Penelitian Kuantitatif, Kualitatif, $P T K, R \& D$. Bumi Aksara. Google Scholar

Copyright holder :

Neovaldo Sitinjak (2021)

First publication right :

Jurnal Syntax Idea

This article is licensed under:

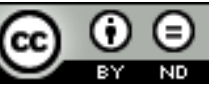

